\title{
KOMPRESIBILITAS TANAH ORGANIK
}

\author{
Asriwiyanti Desiani \\ Dosen Tetap, Program Studi Teknik Sipil, Fakultas Teknik, Universitas Kristen Maranatha \\ Jalan Prof. drg. Suria Sumantri, MPH. No. 65 Bandung 40164 \\ Email: asriwiyanti@gmail.com
}

\begin{abstract}
ABSTRAK
Pembangunan di atas tanah organik umumnya menimbulkan masalah karena tanah tersebut sangat lunak, basah, dan memiliki karakteristik kompresibilitas tinggi. Identifikasi tanah organik sebelum suatu konstruksi terlanjur dibangun dapat mengantisipasi potensi permasalahan yang mungkin terjadi dan melakukan tindakan pencegahan terhadap kerusakan. Penentuan parameter kompresibilitas tanah organik penting dilakukan untuk mencegah permasalahan kelongsoran dan keruntuhan pondasi. Perkiraan jumlah material organik yang berlebihan dapat menuntun pada perlakuan khusus/perbaikan tanah yang mungkin sebenarnya tidak perlu dilakukan ataupun sebaliknya. Uji parameter kompresibilitas tanah organik dikaji berdasarkan hasil uji laboratorium maupun berdasarkan uji in situ. Alat uji untuk mendapatkan parameter kompresibilitas adalah uji oedometer. Alat uji lapangan untuk mendapatkan parameter kompresibilitas yang dikaji adalah CPT, CPTu, vane shear lapangan, dan dilatometer. Studi kasus memperlihatkan nilai indeks pemampatan dari tanah organik di Bandung berkisar antara 2.13-4.21. Studi kasus memperlihatkan nilai tekanan pra konsolidasi dari tanah organik di Bandung yang berkisar antara $0.23-1.9 \mathrm{Kg} / \mathrm{cm}^{2}$.
\end{abstract}

Kata Kunci: kompresibilitas, tanah organik.

\begin{abstract}
The constructions above organic soil generally cause problem because the soil was very soft, wet, and has high compressibility characteristics. Indentification of organic soil before the construction has been built can anticipate potential problems that may occur and take preventive measures against damage. Determination of compressibility parameters of organic soil is important to prevent soil erosion problems and foundation collapse. Estimate of excessive amounts of organic material can lead to special treatment/soil improvements that may not actually need to be done or otherwise. Tests for compressibility parameters of organic soil were examined based on laboratory test result and based on in situ test. The test equipment to obtain compressibility parameters is the oedometer test. Field test equipment to obtain compressibility parameters studied were CPT, CPTu, vane shear field, and dilatometer. Case studies show the compression index value of organic soil in Bandung ranges from 2.13-4.21. Case studies show the value of pre-consolidated pressure from organic soils in Bandung ranging from 0.23$1.9 \mathrm{Kg} / \mathrm{cm}^{2}$..
\end{abstract}

Keywords: compressibility, organic soil.

\section{PENDAHULUAN}

\subsection{Latar Belakang}

Tantangan utama ketika berhubungan dengan tanah organik atau pun gambut adalah karakteristiknya. Karakteristik yang unik dari tanah organik adalah kadar air yang tinggi, kompresibilitas tinggi, kecepatan dan besar creep yang tinggi, kadar organik tinggi dan kekuatan rendah yang mengakibatkan proses konstruksi sering bermasalah (Mundro., 2004; Zainorabidin and Wijeyesekera., 2007; Haan and Kruse., 2006, I. Bakar., 2014). 
Ketika tanah menggalami peningkatan tegangan tekan akibat pondasi, akan terjadi pemampatan tanah (umumnya disebut settlement) yang terdiri dari pemampatan elastis (immediate settlement), pemampatan primer (consolidation settlement) dan pemampatan sekunder (secondary compression). Tanah organik memiliki sifat memampat sangat tinggi, karena itu proses settlement memakan waktu sangat lama.

Tanah gambut secara geoteknik merupakan tanah bermasalah dimana proses pemampatan dan penurunan memerlukan waktu yang panjang yang meningkat saat muka air tanah menurun. Disamping penurunan/settlement, masalah stabilitas selama konstruksi seperti keruntuhan daya dukung dan keruntuhan slip perlu dipertimbangkan. (Duraisamy et al., 2009).

Mengingat kelemahan tanah organik tersebut maka membangun di atas tanah organik cenderung dihindari. Namun kebutuhan lahan yang semakin meningkat, menyebabkan pembangunan pada lahan organik terkadang tak dapat dihindari. Maka sangat penting untuk dapat menentukan parameter kuat geser dan kompresibilitas yang sesuai untuk desain seperti juga harus ditemukan teknik konstuksi yang sesuai untuk material ini.

\subsection{Maksud dan Tujuan studi}

Maksud studi ini adalah melakukan pengkajian terhadap parameter kompresibilitas dari tanah organik. Tujuan studi adalah mendapatkan batasan-batasan parameter kompresibilitas tanah organik serta korelasi dengan uji in situ sehingga dapat digunakan untuk desain maupun mengatasi masalah-masalah yang timbul akibat konstruksi.

\subsection{Ruang Lingkup}

Ruang lingkup studi meliputi:

1. Parameter kompresibilitas;

2. Indeks kompresi, kompresi sekunder dan kompresi tersier.

\subsection{Metode Pendekatan}

Properti kompresibilitas tanah organik dari berbagai sumber pustaka disajikan dengan memperhatikan prosedur uji, korelasi dan data-data hasil uji di laboratorium, maupun data hasil uji lapangan. 


\section{TINJAUAN PUSTAKA}

\subsection{Kompresibilitas (Kemampu mampatan) Tanah Organik}

Secara umum parameter konsolidasi tanah dapat ditentukan menggunakan uji laboratorium, uji in situ dan hitung balik dari pengukuran lapangan. Uji laboratorium memungkinkan simulasi kondisi tegangan dan drainase dengan akurat, namun ketergangguan sampel tanah cukup besar. Uji in situ relatif cepat dan akurat dalam proses identifikasi tanah namun untuk penentuan parameter kuat geser maupun kompresibilitas tidak dapat ditentukan langsung, membutuhkan korelasi dengan hasil laboratorium. Hitung balik dari pengukuran lapangan dapat memberikan hasil yang baik pada beberapa parameter desain tertentu.

Bo et al., (2003) memaparkan berbagai uji untuk pengukuran parameter konsolidasi. Pengujian konsolidasi di laboratorium, antara lain menggunakan alat Oedometer dan Rowe cell. Sedangkan pengujian konsolidasi di lapangan dapat menggunakan Piezocone dissipation test (CPTU), Pressuremeter or self-boring pressuremeter (SBPM) test, Flat dilatometer test (DMT), dan Field permeabilty test (e.g., BAT permeameter).

Analisis balik bisa dilakukan menggunakan data pengukuran tekanan air pori dan pengukuran settlement langsung di lapangan.

Dari hasil pengujian Oedometer dapat ditentukan parameter cv, kv(pengukuran tidak langsung), $\mathrm{C}_{\mathrm{c}}, \mathrm{C}_{\mathrm{r}}, \sigma_{\mathrm{p}}{ }_{\mathrm{p}}$, dan $\mathrm{C}_{\alpha}$, sedangkan dari hasil pengujian Rowe cell dapat ditentukan parameter $\mathrm{c}_{\mathrm{h}}$ dan $\mathrm{k}_{\mathrm{h}}$.

Dari hasil pengujian CPTU dapat ditentukan parameter $\mathrm{c}_{\mathrm{h}}$ dan $\mathrm{k}_{\mathrm{h}}$ yang didasarkan pada uji disipasi tekanan air pori. Hasil pengujian SBPM dapat ditentukan parameter $c_{h}$ dan $\mathrm{k}_{\mathrm{h}}$ yang didasarkan pada uji disipasi tekanan lateral atau tekanan air pori. Hasil pengujian DMT dapat ditentukan parameter $c_{h}$ dan $k_{h}$ yang didasarkan pada tegangan lateral. Dan hasil pengujian permeabilitas lapangan dapat ditentukan parameter $\mathrm{k}_{\mathrm{h}}$ menggunakan piezometer.

Dari hasil analisis balik dapat ditentukan parameter $c_{h}$ menggunakan piezometer dan settlement gauges. 

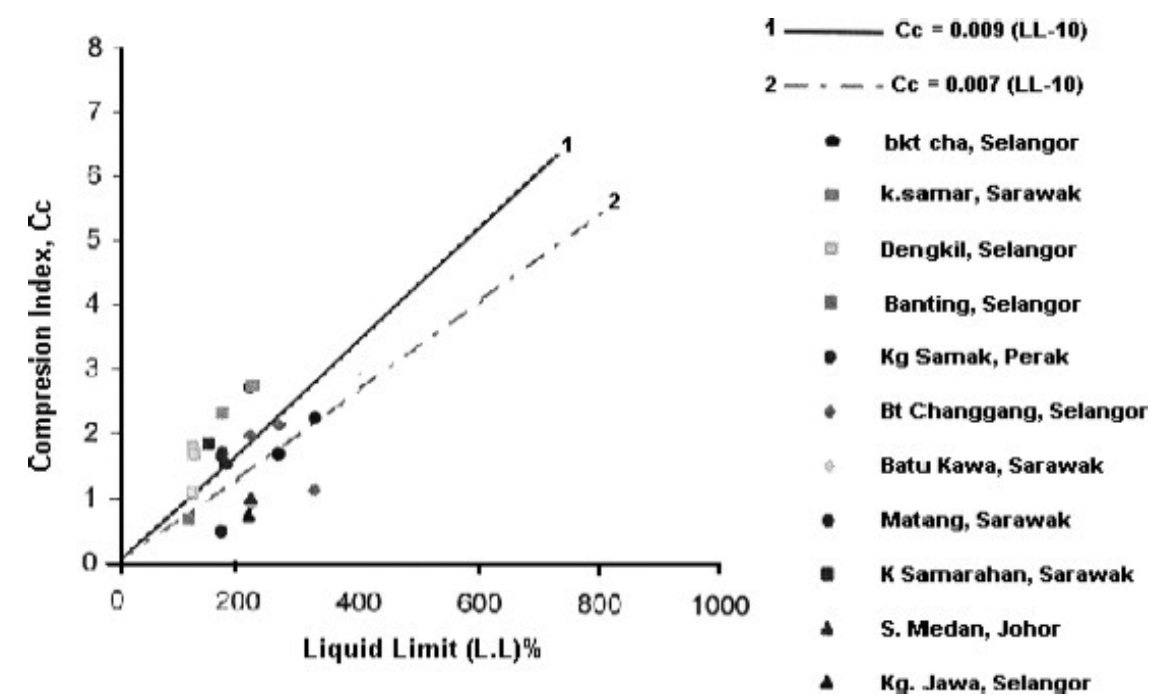

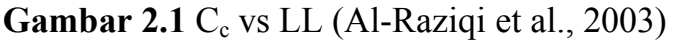

\subsubsection{Parameter Kompresibilitas Tanah Organik Berdasar Hasil Uji Laboratorium}

1. Indeks Pemampatan $\mathrm{Cc}$ dan angka pori

Al-Raziqi et al 2003 melakukan korelasi antara nilai indeks pemampatan $C_{c}$ dengan liquid limit untuk berbagai tanah organik dan gambut di Malaysia dengan menggunakan korelasi acuan dari Skempton dan Petley (1970) $C_{c}=0.009$ (LL-10) serta Hobbs (1986) $\mathrm{C}_{\mathrm{c}}=0.007(\mathrm{LL}-10)$.

Azzouz et al., 1976 memberikan hubungan antara kadar air tanah organik (wn) dengan $\mathrm{C}_{\mathrm{c}}$ sebagai berikut $\mathrm{C}_{\mathrm{c}}=0.0115$.wn.

Den Haan, (1997) mengajukan korelasi untuk gambut di Belanda dimana angka pori dapat ditentukan berdasarkan nilai kadar air dengan mengikuti rumus 2.1 sebagai berikut:

$e_{\mathrm{o}}=30.65 \frac{\left(w_{\mathrm{o}}+0.88\right)^{0.116}}{1.12}-30$

Al-Raziqi et al., (2003) menemukan bahwa korelasi antara parameter settlement $\mathrm{C}_{\mathrm{c}} /(1+\mathrm{e} 0)$ dengan batas cair memiliki kecenderungan meningkat.

2. Koefisien Konsolidasi, $\mathrm{C}_{\mathrm{v}}$

Farrel et al., (1994) mencatat bahwa koefisien konsolidasi menurun sejalan dengan meningkatnya tegangan efektif di atas tegangan pra konsolidasi dan nilai tersebut semakin kecil bila kadar organik tanah semakin besar (Gambar 2.2). 


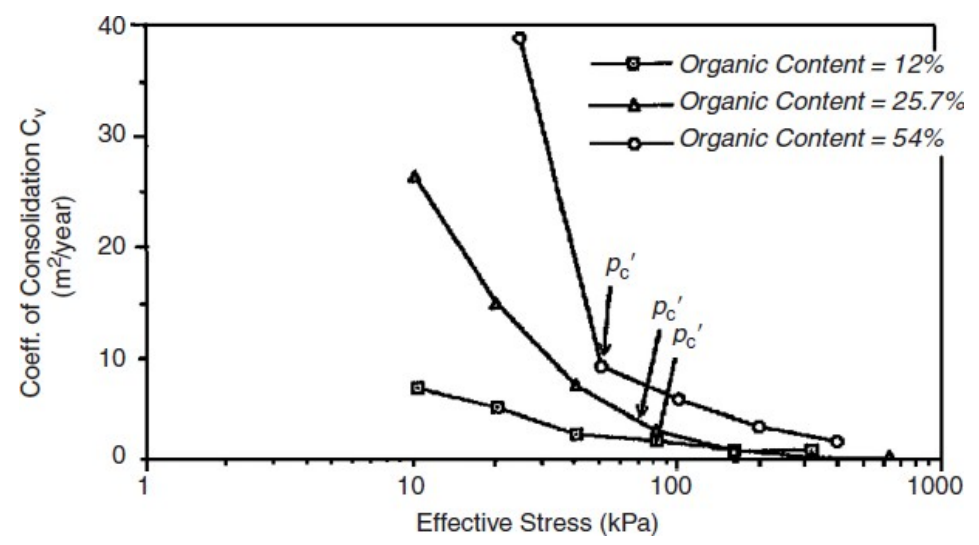

Gambar 2.2 Tegangan efektif vs $\mathrm{C}_{\mathrm{v}}$ (Farrel et al., 1994)

Oikawa dan Igarashi, (1997) mengajukan persamaan untuk menghitung $\mathrm{C}_{\mathrm{v}}$ dari nilai kadar air sebagai berikut:

$$
\begin{aligned}
e_{f}=2.47 & {\left[1-\frac{1}{\exp \left(\frac{2.91}{p}\right)^{0.39}}\right] w_{n}^{0.85\left[1-\frac{1}{\operatorname{cxp}\left(1.85 p^{0.45}\right.}\right]} } \\
\log c_{v}= & {\left[\frac{1.51}{W_{n}}+0.20\right]\left[\frac{e_{o}+e_{f}}{2}\right]-\frac{1.12}{\left(W_{n}-0.21\right)^{0.68}}+\log \frac{\left(1+e_{o}\right)}{e_{o}-e_{f}} } \\
& +\log \left(p-p_{o}\right)-1.06
\end{aligned}
$$

dimana $e_{\mathrm{f}}$ dan $\mathrm{e}_{0}$ merupakan angka pori final dan awal, wn merupakan kadar air, dan $\mathrm{p}$ merupakan tekanan pra konsolidasi dalam satuan $\left(\mathrm{kg} / \mathrm{cm}^{2}\right) . \mathrm{C}_{\mathrm{v}}$ dalam satuan $\mathrm{cm} / \mathrm{s}$.

3. Pemampatan Sekunder

Pemampatan sekunder atau creep yang ditentukan seperti untuk pemampatan satu dimensi dari tanah adalah pemampatan volumetric yang berlanjut dibawah tegangan efektif vertikal yang konstan. Komponen yang bergantung pada waktu dari settlement total terjadi setelah seluruh tekanan air pori berlebih terdisipasi, suatu tahap yang dianggap terjadi setelah konsolidasi primer berakhir.

Estimasi konsolidasi sekunder sering disederhanakan dengan asumsi penurunan sekunder bervariasi secara linier dengan logaritma waktu. Holtz dan Kovacs, (1981) mendefinisikan koefisien konsolidasi sekunder $\mathrm{C}_{\alpha}$ sebagai berikut:

$\left.c_{\mathrm{a}}=\frac{\Delta H}{H_{o}}\left(\log (t p+\Delta t) / t_{p}\right)\right)$

dimana $\mathrm{H}_{\mathrm{o}}$ merupakan ketebalan lapis, $\Delta \mathrm{t}$ merupakan pertambahan waktu yang dihasilkan selama pemampatan sekunder $\Delta \mathrm{H}, \mathrm{t}_{\mathrm{p}}$ adalah waktu dimana konsolidasi primer selesai.

Farrel et al., (1994) memberikan hubungan antara kadar air tanah organik (wn) dengan $\mathrm{C}_{\alpha}$ sebagai berikut $\mathrm{C}_{\alpha}=0.00018$.wn. 
Hobbs (1986) menemukan kecenderungan bahwa nilai $\mathrm{C}_{\alpha}$ konstan untuk kadar air diatas $250 \%$, Hobbs juga menemukan bahwa $\mathrm{C}_{\alpha}$ tanah organik memiliki nilai antara 0.02 -0.04 .

Tanah organik memperlihatkan kemampu mampatan yang lebih tinggi daripada material geoteknik lainnya (Mesri et al, 1997). Pertama, tanah organik memiliki kadar air alami dan angka pori yang lebih tinggi dari pada tanah anorganik dan kedua, tanah organik memiliki nilai $\mathrm{C}_{\alpha} / \mathrm{C}_{\mathrm{c}}$ tertinggi (Mesri dan Godlewiski, 1977; Mesri et al, 1994).

Wong (2003) menjelaskan berdasarkan pengalaman lapangan pada proyek timbunan tanah, tanah organik menunjukkan tahapan konsolidasi primer yang pendek dan cepat. Hal ini diikuti dengan pemampatan sekunder atau pemampatan creep yang lambat dan berkelanjutan.

Perhitungan settlement memerlukan evaluasi parameter tanah dari lengkung pemampatan yang biasanya di dapat dari uji Oedometer. Hasil dari uji Oedometer dengan incremental loading biasanya disajikan sebagai hubungan antara angka pori vs tegangan vertikal efektif $\sigma_{\mathrm{v}}$. Tegangan vertikal efektif dapat di plot pada skala linier untuk menentukan koefisien perubahan volume, mv dan modulus Oedometer, $\mathrm{M}$, atau pada skala logaritmik untuk menentukan indeks pemampatan, $\mathrm{C}_{\mathrm{c}}$.

Kirov (2003) menemukan saat tanah organik di uji Oedometer, jadwal pembebanan yang digunakan memiliki pengaruh cukup besar pada hasil uji. Ia menyarankan lebih baik menggunakan jadwal pembebanan individual semirip mungkin dengan perkiraan pembebanan in situ. Jika jadwal lain digunakan, nilai koefisien pemampatan yang didapat mungkin tidak tepat. Hal ini dapat menyebabkan kesalahan dalam perhitungan settlement.

S. Kamao (2014) dari Nihon University, Jepang melakukan uji creep di laboratorium untuk tanah highly organic dari daerah Tokyo, Jepang. Tanah yang diuji memiliki kadar organik rendah sampai tinggi. Uji creep dilakukan untuk kondisi loading dan unloading pada berbagai nilai OCR $(1.0$ - 16.0). Hal ini bertujuan untuk menentukan nilai OCR yang pantas digunakan saat mendesain memakai metode preloading. Selain uji creep dilakukan pula uji relaxation untuk melihat pengaruh pengurangan settlement jangka panjang yang umumnya terjadi setelah beban preload diangkat. Hasil uji creep menunjukan bahwa kecepatan secondary compression $\varepsilon \alpha$ berkurang sejalan dengan peningkatan nilai OCR, seperti terlihat pada Gambar 2.3. OCR yang sesuai untuk meminimalkan settlement jangka panjang pada tanah highly organic berkisar pada nilai 2 . Hasil uji relaxation menunjukan penggurangan tekanan konsolidasi tergantung pada jenis tanah. 


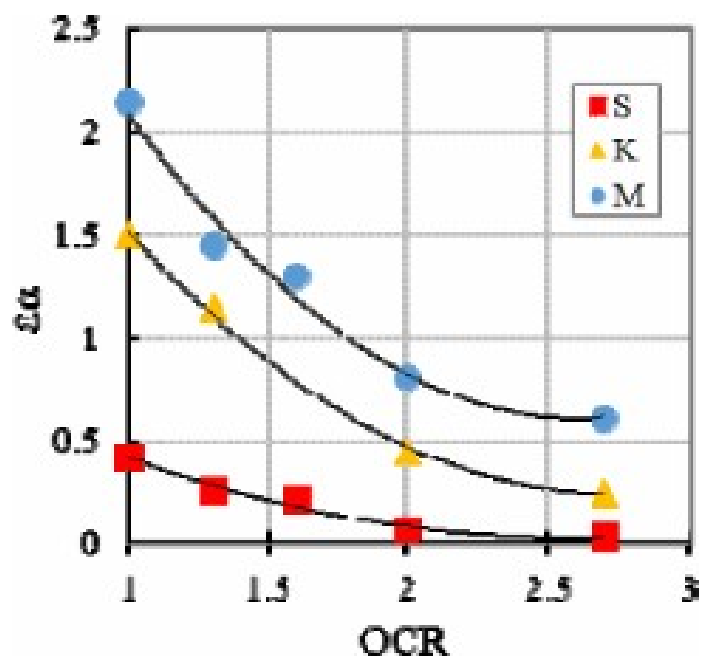

Gambar 2.3 Hubungan antara nilai kompresi sekunder dengan OCR

H. J. Lengkeek et al., (2014) mempresentasikan perilaku tanah organik yang diuji memakai berbagai peralatan di laboratorium. Uji dilakukan dalam rangka melakukan verifikasi terhadap kestabilan tanggul banjir di Belanda. Alat uji yang digunakan antara lain : Oedometer (OED), Constant rate of strain (CRS), Triaxial CU Anisotropis, dan Direct shear.

Hasil uji menunjukan nilai kadar air yang tinggi dan berat volume yang rendah. Hal ini menunjukan kadar organik tanah tersebut tinggi. Hasil uji CRS akan dipakai untuk menentukan tegangan prakonsolidasi yang dapat dipercaya. Dari hasil CRS dan perhitungan tegangan efektif insitu dapat ditentukan tegangan konsolidasi.

Uji triaxial CU anisotropi tidak dapat diaplikasikan pada tanah organik. Rasio $\mathrm{Su}$ bervariasi antara 0.46 dan 0.53 dengan kekuatan $0.87-1$.

Secara umum parameter kuat geser pada studi kasus ini lebih tinggi jika dibandingkan dengan parameter kuat geser tanah kohesif yang biasa. Penjelasan tentang perilaku dapat dihubungkan kepada kadar organik dan kadar air yang tinggi. Pada material organik keberadaan serat pada tanah dapat mengakibatkan kuat tarik menjadi tinggi sehingga kuat geser tanah meningkat.

Tanah organik dapat mengalami konsolidasi, pemampatan, dan penurunan akibat dibebani dua cara:

a. Secara lambat,

Konsolidasi dan pemampatan terjadi berangsur-angsur sehingga tanah organic memiliki waktu untuk bereaksi terhadap beban. Metode ini sesuai untuk membangun jalan di atas tanah organik. Metode ini juga memberi waktu bagi tanah organik untuk menambah kekuatan dan daya dukung. 
b. Secara cepat,

Tanpa perubahan volume dan dengan penyebaran dan pergeseran secara cepat menyebabkan kegagalan. Tanah organik sangat rentan terhadap tegangan geser yang berlebihan. Pembebanan perlu diatur secara hati- hati untuk menjaga tegangan geser yang terjadi tetap dalam jangkauan kekuatan tanah.

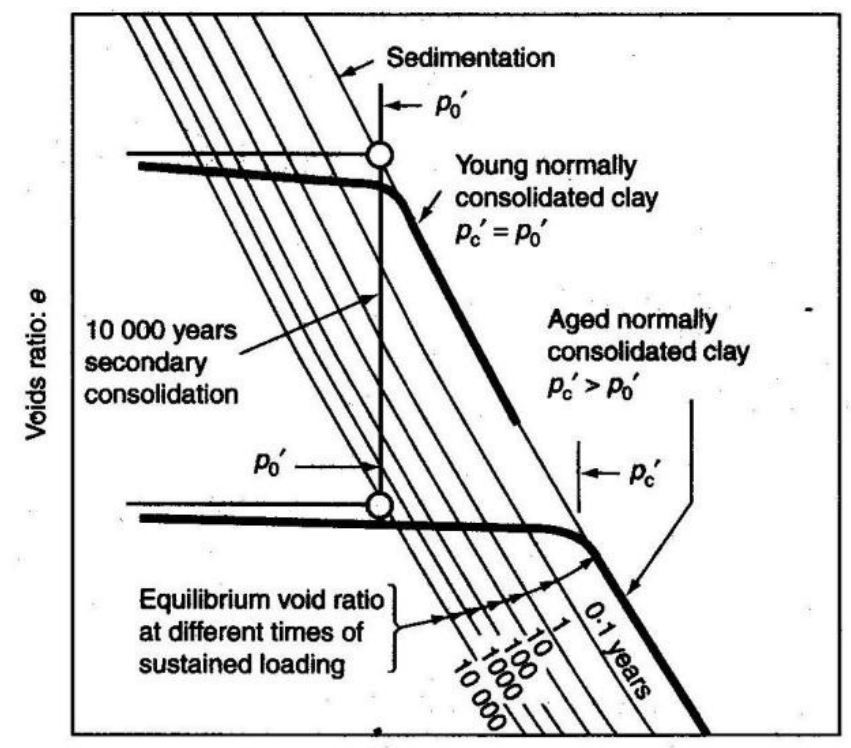

Vertical pressure (logarithmic scale)

Gambar 2.4 Hubungan voids ratios-log effective pressure-time, Bjerrum (1967)

Pemampatan awal langsung terjadi setelah beban diaplikasikan. Pemampatan primer dan sekunder bergantung pada lamanya pembebanan diaplikasikan. Pemampatan awal secara umum terjadi karena pemampatan gas dalam pori dan juga pemampatan elastis dari butiran tanah. Konsolidasi primer yang diamati saat terjadi peningkatan tegangan vertikal efektif menyebabkan disipasi tekanan air pori berlebih. Setelah disipasi selesai, pemampatan sekunder berjalan dengan tegangan vertikal efektif konstan.

Perilaku pemampatan tanah organik berbeda dalam dua hal dari perilaku pemampatan tanah anorganik. Pertama, pemampatan tanah organik jauh lebih besar dari tanah anorganik. Kedua, creep settlement memiliki peran yang lebih signifikan dalam menentukan settlement total tanah organik dibandingkan dengan tanah anorganik.

Kazemian dan Huat (2009) menyatakan konsolidasi primer dari fibrous peat terjadi dengan sangat cepat, pemampatan sekunder besar, bahkan pemampatan tersier, juga terjadi. 
Mesri dan Ajlouni (2007) menjelaskan tentang faktor dominan yang mengatur sifat pemampatan tanah organik antara lain, kadar serat, kadar air alami, angka pori, permeabilitas awal, susunan partikel tanah dan ikatan kimia antar partikel. Penentuan pemampatan fibrous peat biasanya didasarkan pada uji konsolidasi standar.

Angka pori in situ fibrous peat sangat tinggi karena fibrous peat berupa serat seluler berongga yang membentuk sebuah jaringan partikel berkaitan serta terbuka, sehingga kadar air awal tinggi. Saat pemampatan primer ataupun sekunder, air dikeluarkan secara bersamaan dari dalam dan di antara partikel gambut. Maka dari itu kurva e-log p menunjukkan sebuah kemiringan curam yang menunjukkan nilai indeks pemampatan yang tinggi.

Indeks pemampatan tanah organik berkisar antara 2-15. Selain itu ada kemungkinan bahwa pemampatan sekunder dimulai sebelum disipasi tekanan air pori berlebih selesai.

Berat volume tanah organik nilainya mirip dengan berat volume air sehingga tegangan efektif in situ sangat kecil dan terkadang tidak dapat dideteksi dari hasil uji konsolidasi. Penentuan awal pemampatan sekunder (tp) dari kurva konsolidasi sangat sulit karena konsolidasi yang mendahului terjadi sangat cepat. (Yulindasari, 2006).

Pemampatan fibrous peat berlanjut dengan kecepatan yang berangsur-angsur berkurang dan tegangan efektif yang konstan. Hal ini disebut pemampatan sekunder. Pemampatan sekunder tanah organik karena penguraian lebih lanjut dari serat yang diasumsikan berjalan dengan laju yang lebih lambat setelah konsolidasi primer berakhir. Kemiringan bagian akhir kurva angka pori vs log waktu (C) didefinisikan sebagai laju pemampatan sekunder. Perkiraan ini didasarkan atas asumsi bahwa $\mathrm{C}$ tidak terikat oleh waktu, ketebalan lapisan yang dapat dimampatkan, dan tekanan yang diaplikasikan. Rasio $\mathrm{C} / \mathrm{C}_{\mathrm{c}}$ sudah digunakan secara luas untuk mempelajari sifat tanah organik dan besarnya berkisar antara 0.05-0.07 diteliti oleh Mesri et al. (1997).

Meskipun laju konsolidasi primer dari fibrous peat sangat tinggi, hal ini berkurang dengan aplikasi tekanan konsolidasi menurut Lea dan Brawner (1963) laju koefisien konsolidasi akan mengalami penurunan signifikan pada saat aplikasi tekanan dari $10-100 \mathrm{kPa}$. Faktor reduksi signifikan sebesar 5-100 dikenakan terhadap reduksi permeabilitas yang disebabkan oleh peningkatan tekanan.

Pada beberapa jenis gambut dan tanah organik, parameter settlement nya dapat ditentukan memakai uji oedometer standar. Bentuk umum kurva konsolidasi akan tampak serupa dengan kurva tanah anorganik. Tetapi terdapat tanah berkadar organik dan material serat dengan penghumusan tingkat rendah, yang tidak mengikuti konsep 
pemampatan lempung konvensional . Hal ini disebabkan karena perbedaan sifat fase padat dan mikrostruktur tanah tersebut. Bila tanah organik ini tetap di analisa memakai metode konvensional, maka kemiripan dengan kurva tanah anorganik sangat sedikit. Perbedaan ini akan sangat jelas terlihat pada tegangan vertikal rendah (peningkatan beban awal di laboratorium). Material seperti itu juga rawan terhadap penguraian selama uji oedometer. Kadar gas dan produksi gas lain juga dapat memperumit interpretasi dari uji oedometer. Perilaku tanah organik dan perumusan perilaku tanah tersebut diteliti oleh Edil (1997) dan Haan (1997).

\section{Pemampatan Tersier}

Proses konsolidasi, pemampatan dan settlement tanah organik dapat terdiri dari tiga fase yaitu: settlement secara instan/pemampatan awal, konsolidasi primer, dan pemempatan sekunder. Oleh beberapa sumber disebut pula adanya tahapan ke empat yaitu settlement tersier seperti terlihat pada Gambar 2.5.

Edil dan Dhowian, (1979) melaporkan kurva kompresi pada uji oedometer untuk gambut Wisconsin memperlihatkan terdapat bagian yang curam bila diplot terhadap skala logaritma waktu. Bagian tersebut didefinisikan sebagai fase pemampatan tersier yang terjadi setelah fase pemampatan sekunder. Pada tahun 1980 keduanya mendefinisikan ulang pemampatan tersier sebagai bagian yang curam dari kurva logaritma regangan natural. Pemampatan tersier diperkenalkan pula sebagai alat yang ditujukan untuk mengingkatkan $\mathrm{C}_{\alpha}$ terhadap waktu.

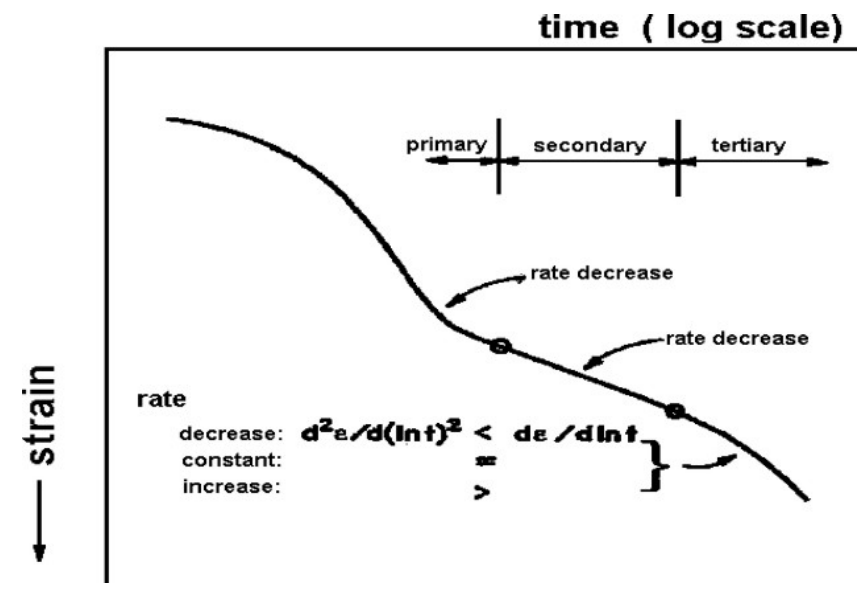

Gambar 2.5 Pemampatan primer, sekunder, dan tersier (Huat et al., 2014) 


\subsubsection{Parameter Kompresibilitas Tanah Organik Berdasar Hasil Uji In Situ}

Uji in situ sangat berguna karena dapat mencegah masalah masalah yang berkaitan dengan kesulitan pengambilan sampel tanah. Sayangnya belum banyak pembahasan tentang uji in situ dan korelasi dengan parameter konsolidasi khusus untuk tanah organik. Uji in situ yang akan dilaporkan untuk menentukan parameter konsolidasi tanah organik antara lain uji Dilatometer dan Piezocone (CPTu).

Rahardjo, Yunan, dan Lento (2009) meneliti tanah lunak dan tanah gambut di Pelintung, Sumatera menggunakan Marchetti Dilatometer dan Dual Dilatometer yang dikembangkan oleh Parahyangan Catholic University (UNPAR DDMT). Korelasi dan interpretasi untuk nilai OCR berdasarkan rumus empiris adalah sebagai berikut

3. Marchetti, 1980

$$
O C R=\left(0.5 K_{D}\right)^{2.86} \text { for } I_{D} r_{m} 1.2(\text { flay })
$$

4. Larsson dan Eskilson (1989)

$$
Q \mathrm{QRK}=10^{0.46(\mathrm{KD}-2.8 \mathrm{~B})}
$$

5. Kamei dan Iwasaki (1995)

$$
0 \mathrm{CR}=0.34 K_{2}{ }^{1.48}
$$

6. Chang (1991a), untuk Singapore soft marine's clay

$$
Q C R=\left(0.5 K_{D}\right)^{0.84}
$$

Nilai OCR hasil interpretasi semua metode di atas lebih kecil dari 1. Hal ini mengindikasikan proses konsolidasi tanah gambut di Pelintung masih berjalan (under consolidated). Secara umum nilai Kd lebih kecil dari 2 menghasilkan nilai OCR lebih kecil dari 1.

Rahardjo, et al. (2006) menjelaskan dan menggunakan uji disipasi pada uji Piezocone untuk memonitor besarnya derajat konsolidasi pada satu waktu tertentu dan menentukan koefisien konsolidasi arah horizontal, ch. Pada saat melakukan uji piezocone di tanah lunak, penetrasi konus akan menghasilkan tekanan air pori ekses yang terbaca pada sensor tekanan air pori. Besar koefisien konsolidasi dapat diketahui dengan melakukan tes disipasi, dimana tekanan air pori ekses dibiarkan terdisipasi sampai dengan tekanan air pori ekses yang terukur mendekati nilai tekanan hidrostatisnya. Karena arah aliran tekanan air pori ekses dalam pengujian ini radial maka nilai koefisien konsolidasi yang didapatkan merupakan koefisien konsolidasi dalam arah horizontal.

Pertama, tekanan air pori ekses diplot mengikuti metode Asaoka dengan sumbu $u_{t}$ dan $u_{t}+\Delta_{t}$ dimana $u_{t}$ adalah tekanan air pori ekses pada suatu waktu. Dengan menggunakan kurva pada metode Asaoka dapat ditentukan nilai $\mathrm{u}_{\mathrm{f}}$ dan $\mathrm{u}_{50}$. 
Kedua, tekanan air pori ekses selama disipasi diplot dalam grafik terhadap log waktu, menggunakan nilai $\mathrm{u}_{50}$ yang di dapat dari langkah 1, dapat ditentukan $\mathrm{t}_{50}$. Nilai koefisien konsolidasi arah horizontal, ch ditentukan menggunakan chart dari Robertson et al. (1992) berdasarkan waktu yang diperlukan untuk mencapai 50\% disipasi.

Anastasia, As win, Andy (2012) melakukan studi korelasi tahanan ujung sondir terhadap sifat kemampatan lempung di Bandung. Korelasi qc dengan kompresibilitas menggunakan formula Mitchell dan Gardner (1975) yakni:

$\alpha=1 /\left(\mathrm{m}_{\mathrm{v}} \cdot \mathrm{q}_{\mathrm{c}}\right)$

dimana:

$\alpha=$ koefisien yang bergantung pada nilai qc

$\mathrm{m}_{\mathrm{v}}=$ Koefisien pemampatan volume $\left(\mathrm{cm}^{2} / \mathrm{kg}\right)$

$\mathrm{q}_{\mathrm{c}}=$ Tahanan ujung sondir $\left(\mathrm{kg} / \mathrm{cm}^{2}\right)$

Hasil uji untuk tanah organik Gedebage menghasilkan nilai $\mathrm{q}_{\mathrm{c}}$ berkisar 4.1-14.5 $\mathrm{kg} / \mathrm{cm} 2$, koefisien pemampatan mv antara $0.048-0.137 \mathrm{~cm}^{2} / \mathrm{kg}$, dan nilai $\alpha$ berkisar pada $0.26-11.1$.

\subsubsection{Back Analysis}

Memprediksi besar dan waktu settlement memainkan peran utama di dalam proyek-proyek perbaikan tanah yang menggunakan metode pre-loading. Prediksi yang akurat tergantung pada pemilihan parameter tanah dan keputusan engineer. Engineer harus memverifikasi kelayakan tanah dengan menggunakan metode monitoring instrumen selama proses konsolidasi dan sesudahnya.

Instrumen sederhana yang dapat menilai derajat konsolidasi adalah settlement plate dan piezometer. Bo et al (1997).

1. Settlement gauge

Derajat Konsolidasi rata-rata dapat ditentukan secara sederhana berdasarkan settlement. Derajat konsolidasi rata-rata pada suatu waktu ( $\mathrm{t}$ ) sesudah pembebanan dapat ditentukan dengan rumus berikut.

$\overline{\mathrm{U}}(\%)=\mathrm{S}_{\mathrm{t}} / \mathrm{S}_{\alpha}$

dimana :

$\mathrm{S}_{\mathrm{t}}$ adalah settlement pada waktu ( $\left.\mathrm{t}\right)$

$\mathrm{S}_{\alpha}$ adalah settlement konsolidasi primer ultimate $\overline{\mathrm{U}}(\%)$ adalah derajat konsolidasi

Prediksi settlement ultimate dari hasil monitoring lapangan yang lebih akurat dapat dilakukan dengan menganalisa hasil monitoring settlement. Sridharan dan Seepada

Kompresibilitas Tanah Organik (Asriwiyanti Desiani) 
(1981) Menyarankan metode hiperbolik dapat digunanakan untuk memprediksi settlement ultimate. Tan (1993) Melaporkan bahwa metode hiperbolik valid untuk memprediksi settlement ultimate pada perbaikan tanah menggunakan vertical drained hanya bila digunakan faktor kemiringan koreksi yang berhubungan dengan rasio drainase dan ketebalan. Asaoka (1978) mengajukan metode prediksi settlement menggunakan hasil monitoring settlement dan fitting curve.

Suatu perbandingan dilakukan pada hasil monitoring Changi East, Singapore menggunakan tiga metode diatas. Terlihat bahwa derajat konsolidasi dari ketiga metode hasilnya mendekati. Jika digunakan ekstensometer yang dipasang pada sublapisan maka derajat konsolidasi dari sub lapisan dapat diperkirakan dengan mengaplikasikan metode yang sama.

2. Piezometer

Piezometer digunakan untuk mengukur tekanan pori dari tanah. Jika monitoring yang teratur dilakukan untuk mengukur piezometric head bersamaan dengan ketinggian air statik maka disipasi tekanan air pori berlebih dapat dideteksi dan derajat konsolidasi dapat dihitung. Tekanan air pori berlebih rata-rata dapat ditentukan dengan rumus berikut.

$\mathrm{U}(\%)=1-\left(\mathrm{u}_{\mathrm{t}} / \mathrm{u}_{\mathrm{i}}\right)$

Dimana :

$\mathrm{u}_{\mathrm{t}}$ adalah tekanan pori berlebih pada waktu $(\mathrm{t})$ dan

$\mathrm{u}_{\mathrm{i}}$ adalah tekanan pori berlebih initial, besarnya sama dengan pertambahan beban $\left(\Delta \sigma^{\prime}\right)$.

Jika Piezometer dipasang dalam elevasi yang berbeda-beda derajat konsolidasi rata-rata untuk seluruh ketebalan tanah dapat dihitung seperti halnya derajat konsolidasi rata-rata dari sub lapisan tanah. Bo et al., 2003 membandingkan derajat konsolidasi dari hasil monitoring piezometer terhadap hasil monitoring deep settlement gauge dan menemukan bahwa derajat konsolidasi yang dihasilkan sesuai.

\section{PEMBAHASAN DAN ANALISA}

Pembahasan dilakukan terhadap data-data dari tanah Lempung Bandung dengan lokasi pada jalur jalan Tol Padalarang-Cileunyi, antara Km 34 sampai Km 42, yang merupakan daerah cekungan, mengandung sedimen abu vulkanik berdasar laporan hasil penyelidikan tanah oleh LYON/INDEX, 1983 dan DCIL/INDEX, 1985. Deposit tanah terdiri dari beberapa lapisan tanah yang lunak dan basah mencapai kedalaman 30m, mempunyai kandungan air yang sangat tinggi mencapai lebih dari 200\%. Data kedalaman Bor dan sifat fisik Lempung Bandung dapat dilihat pada tabel 3.1. 
Tabel 3.1 Data kedalaman dan sifat fisik Lempung Bandung (Ma'mun, 1990)

\begin{tabular}{|c|cccccccc|}
\hline Bor No. & \multicolumn{2}{|c|}{ Kedalaman } & w & LL & PL & PI & Gs \\
& \multicolumn{2}{|c|}{$(\mathrm{m})$} & $(\%)$ & $(\%)$ & $(\%)$ & $(\%)$ & \\
\hline B1-2 & 3,10 & - & 3,50 & 193 & 99 & 57 & 42 & 2,33 \\
B2-2 & 3,50 & - & 3,90 & 224 & 233 & 60 & 173 & 2,19 \\
B3-2 & 3,60 & - & 4,00 & 258 & 220 & 75 & 145 & 2,25 \\
B4-1 & 3,80 & - & 4,20 & 248 & 211 & 70 & 141 & 2,17 \\
B5-2 & 3,70 & - & 4,10 & 229 & 215 & 57 & 158 & 2,11 \\
B6-2 & 3,60 & - & 4,00 & 234 & 190 & 53 & 137 & 2,18 \\
B7-2 & 3,50 & - & 3,90 & 220 & 264 & 98 & 166 & 2,10 \\
B8-2 & 3,70 & - & 4,20 & 254 & 212 & 97 & 115 & 2,10 \\
\hline
\end{tabular}

Tabel 3.1 memperlihatkan hasil uji konsolidasi untuk tanah lempung Bandung. Nilai indeks pemampatan $(\mathrm{Cc})$ berkisar antara 2.13 sampai 4.21. Nilai tekanan pra konsolidasi berkisar antara $0.23-1.9 \mathrm{Kg} / \mathrm{cm}^{2}$.

Tabel 3.2 Hasil uji konsolidasi tanah lempung Bandung (Ma'mun, 1990)

\begin{tabular}{|c|c|c|c|c|c|c|c|c|c|c|}
\hline $\begin{array}{c}\text { Bor } \\
\text { No. }\end{array}$ & \multicolumn{7}{|c|}{ Tegangan Konsolidasi $\left(\mathrm{kg} / \mathrm{cm}^{2}\right)$} & \multirow{2}{*}{ Pc } & \multirow{2}{*}{ Cc } \\
\cline { 2 - 9 } & & 0,1 & 0,2 & 0,4 & 0,8 & 1,6 & 3,2 & 6,4 & & \\
\hline B4-2 & e & 5,10 & 5,01 & 4,85 & 4,48 & 3,81 & 3,02 & 2,61 & \multirow{2}{*}{1,2} & \multirow{2}{*}{3,24} \\
& $\mathrm{c}_{\mathrm{v}}$ & 2,44 & 3,81 & 3,66 & 1,14 & 0,43 & 0,17 & 0,26 & & \\
\hline B1-3 & $\mathrm{e}$ & 5,32 & 5,21 & 5,07 & 4,83 & 4,26 & 3,49 & 2,85 & \multirow{2}{*}{1,8} & \multirow{2}{*}{4,21} \\
& $\mathrm{c}_{\mathrm{v}}$ & 3,49 & 2,17 & 2,96 & 4,80 & 2,66 & 0,91 & 0,89 & & \\
\hline B7-1 & $\mathrm{e}$ & 4,07 & 4,03 & 3,97 & 3,86 & 3,58 & 3,04 & 2,28 & \multirow{2}{*}{1,9} & \multirow{2}{*}{3,22} \\
& $\mathrm{c}_{\mathrm{v}}$ & 3,50 & 4,25 & 3,75 & 2,09 & 2,48 & 1,49 & 0,56 & & \\
\hline $\begin{array}{c}\text { B6-3 } \\
\left(^{*}\right)\end{array}$ & $\mathrm{e}$ & 6,28 & 6,11 & 5,77 & 5,41 & 4,94 & 3,69 & 2,93 & \multirow{2}{*}{1,25} & \multirow{2}{*}{4,72} \\
\hline $\begin{array}{c}\text { B4-4 } \\
(\mathrm{x})\end{array}$ & $\mathrm{e}$ & 5,15 & 6,22 & 3,71 & 3,03 & 2,42 & 0,19 & 0,47 & & \\
\hline
\end{tabular}

Catatan: $\quad * \mathrm{~B}_{6-3}$ Pembebanan 2 hari

$x B_{4-4}$ Direndam 4 hari

Hasil uji Atterberg dapat digunakan untuk mencari nilai Cc, karena itu akan dicoba untuk membuat korelasi tanah organik antara nilai LL dan $\mathrm{C}_{\mathrm{c}}$. Rumus yang akan digunakan sebagai acuan diambil dari Skempton dan Petley (1970) $C_{c}=0.009($ LL-10) serta Hobbs (1986) $C_{c}=0.007(L L-10)$. Hasil perhitungan dapat dilihat pada Tabel 3.3 
Tabel 3.3 Perbandingan $\mathrm{C}_{\mathrm{c}}$ Skempton (1970) dan Hobbs (1986)

\begin{tabular}{|c|c|c|c|c|}
\hline \multicolumn{2}{|c|}{ Nilai $\mathrm{C}_{\mathrm{c}}$} & \multirow{2}{*}{$\mathrm{e}_{0}$} & \multicolumn{2}{|c|}{$\mathrm{C}_{\mathrm{c}} /\left(1+\mathrm{e}_{0}\right)$} \\
\cline { 1 - 1 } Skempton & Hobbs & & Skempton & Hobbs \\
\hline 0,801 & 0,623 & 0,85 & 0,43 & 0,34 \\
2,007 & 1,561 & 1,23 & 0,90 & 0,70 \\
1,89 & 1,47 & 1,60 & 0,73 & 0,56 \\
1,809 & 1,407 & 1,50 & 0,72 & 0,56 \\
1,845 & 1,435 & 1,28 & 0,81 & 0,63 \\
1,62 & 1,26 & 1,34 & 0,69 & 0,54 \\
2,286 & 1,778 & 1,18 & 1,05 & 0,82 \\
1,818 & 1,414 & 1,56 & 0,71 & 0,55 \\
\hline
\end{tabular}

Gambar 3.2 memperlihatkan hubungan antara $C_{c}$ vs LL dari lempung Bandung dan mengikuti trend yang sama dengan trend yang dihasilkan oleh Farrel et al, (1994).

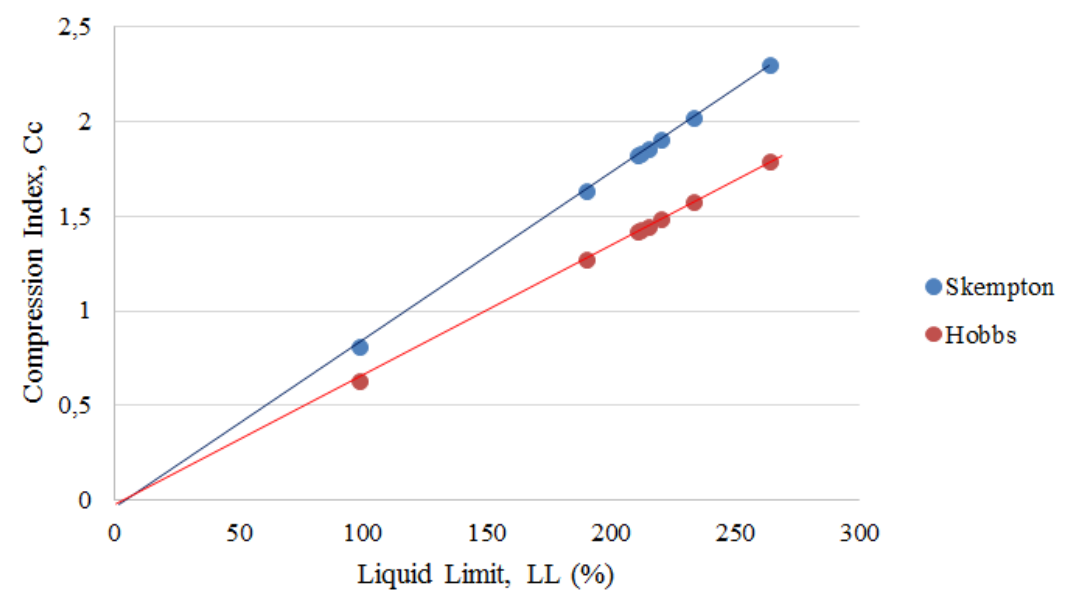

Gambar 3.1 Hubungan $C_{c}$ vs LL

Gambar 3.2 memperlihatkan hubungan antara $\mathrm{C}_{\mathrm{c}} /\left(1+\mathrm{e}_{0}\right)$ vs $\mathrm{LL}$ dari lempung Bandung yang memiliki trend peningkatan batas cair sejalan dengan peningkatan parameter settlement. 


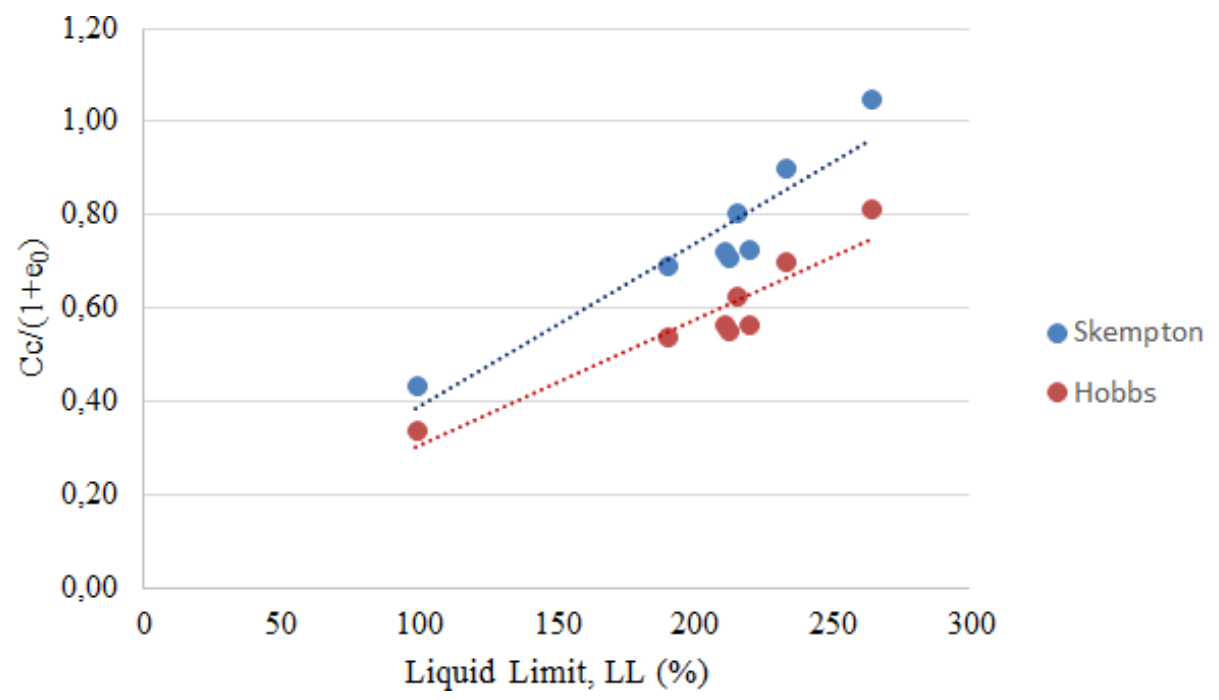

Gambar 3.2 Hubungan antara $\mathrm{C}_{\mathrm{c}} /\left(1+\mathrm{e}_{0}\right)$ vs $\mathrm{LL}$

Gambar 3.3 memperlihatkan hubungan antara koefisien konsolidasi $\mathrm{C}_{\mathrm{v}}$ dengan tegangan efektif vertikal. Terlihat kecenderungan koefisien konsolidasi menurun sejalan dengan meningkatnya tegangan efektif vertikal, pada tegangan efektif di atas tegangan pra konsolidasi nilai $\mathrm{C}_{\mathrm{v}}$ semua menurun dan lebih landai. Trend ini sesuai dengan trend Farrel et al., 1994.

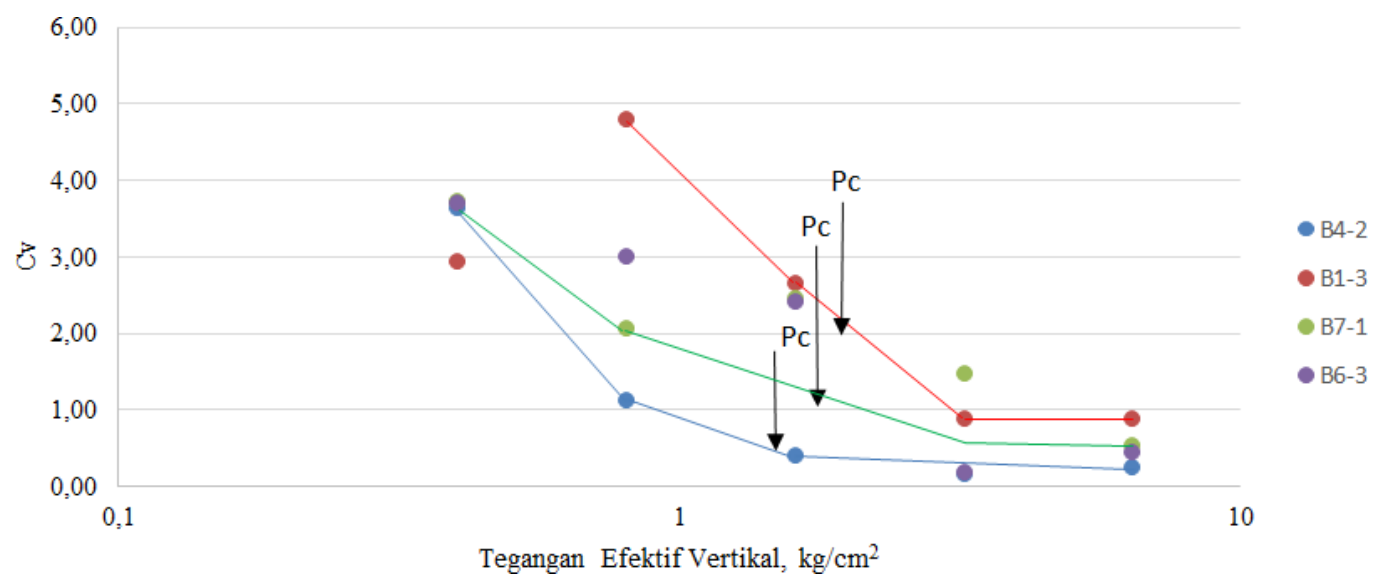

Gambar 3.3 Tegangan efektif vs $\mathrm{C}_{\mathrm{v}}$

\section{SIMPULAN DAN SARAN}

Berdasarkan hasil pengujian kompresibilitas tanah organik maka diperoleh hasil:

1. Kuat geser tanah organik tergantung pada derajat penghumusan, kadar air dan kadar mineral. Semakin tinggi kadar air tanah organik maka kuat geser akan semakin 
rendah. Semakin tinggi derajat penghumusan maka semakin rendah kuat geser. Semakin besar kadar mineral maka kuat geser semakin besar pula.

2. Pengukuran kuat geser tanah organik di laboratorium tidak mudah sehubungan kesulitan mendapatkan sampel tanah yang representative dan untuk membawanya secara cepat ke laboratorium serta memotong sampel sesuai ukuran tanpa terganggu.

3. Uji in situ yang sederhana seperti vane shear test dapat digunakan untuk memberi indikasi kuat geser in situ. Kesempatan untuk mengembangkan alat uji in situ untuk mencari parameter kuat geser dan kompresibilitas masih terbuka lebar.

4. Nilai indeks pemampatan $\mathrm{Cc}$ tanah organik berkisar antara 2.0-15.0, sedangkan untuk pemampatan sekunder digunakan indeks pemampatan sekunder $\mathrm{C} \square$ dengan rentang $\mathrm{C}_{\alpha} / \mathrm{C}_{\mathrm{c}}$ 0.05-0.07.

5. Kazemian dan Huat, (2009) memberikan nilai $\mathrm{C}_{\alpha} / \mathrm{C}_{\mathrm{c}}$ untuk tanah organik di Malaysia yang besarnya $0.07-0.10$.

6. Studi kasus memperlihatkan nilai indeks pemampatan dari tanah organik di Bandung berkisar antara 2.13-4.21.

7. Studi kasus memperlihatkan nilai tekanan pra konsolidasi dari tanah organik di Bandung yang berkisar antara $0.23-1.9 \mathrm{Kg} / \mathrm{cm}^{2}$.

\section{DAFTAR PUSTAKA}

1. Al-Raziqi, A. A., Huat, B. B. K. and Munzir, H. A. (2003) Potential usage of hyperbolic method for prediction of organic soil settlement. Proc. 2nd International Conference on Advances in Soft Soil Engineering and Technology (eds. B. Huat et al.), Putrajaya, Malaysia, pp. 439-45.

2. Bakar, I. (2014). Challenges In Peat Soil Research - Malaysian Experiences. Proceedings of Soft Soils 2014, Bandung, Indonesia, A7.

3. Culloch, F. M. (2006) Guidelines for the risk management of peat slips on the construction of low volume/low cost road over peat. Forestry Civil Engineering Forestry Commission, Scotland, pp. 1-46.

4. Edil, T. B. and Dhowian, A. W. (1981) At-rest lateral pressure of peat soils. Journal of the Geotechnical Engineering Division, 107(GT2), 201-17.

5. Farrell, E. R. (1998) The determination of geotechnical parameters of organic soils. Problematic Soils (eds. E. Yanagisawa, N. Moroto and T. Mitachi), Balkema, Rotterdam, pp. 33-6.

6. Haan D.E.J., Kruse G. A. M., (2006). Characterisation and engineering properties of Dutch peats. Characterisation and Engineering Properties of Natural Soils. 
Proceedings of 2nd Int. Workshop, Singapore, Taylor \& Francis, London, 2007, 3:2101-2133.

7. Hanzawa, H. (1991). A Newe Approach to Determine the Shear Strength of Soft Clay. Proceedings of GEO-COAST 1991, Yokohama, Japan.

8. Huat, B.B.K. (2004) Organic and Peat Soils Engineering. 1st edn. University Putra Malaysia Press, Serdang, Malaysia.

9. Huat, B.B.K., Prasad, A., Asadi, A., Kazemian, S. (2014). Geotechnics of Organic Soils and Peat. CRC Press.

10. Kamao, S. (2014) Characteristic of long-term resettlement of soft ground after removal of the preload. Proceedings of Soft Soils 2014, Bandung, Indonesia, F3.

11. Kazemian, S. and Huat, B. B. K. (2009a) Compressibility characteristics of fibrous tropical peat reinforced with cement column. Electronic Journal of Geotechnical Engineering, 14C. Kazemian, S., Huat, B. B. K. and Moayedi, H. (2012b) Undrained shear characteristics of. tropical peat reinforced with cement stabilized soil column, Geotechnical and Geological Engineering Journal, DOI:10.1007/s10706-012-9492-7.

12. Kazemian, S., Prasad, A., Huat, B. B. K. and Barghchi, M. (2011a) A state of an art review of peat from general perspective. International Journal of the Physical Sciences, 6(8), 1988- 96.

13. Kazemian,S., Huat, B.B.K., Prasad,A., and Barghchi,M., (2011). A State Review of Peat: Geotechnical Engineering Perspective. International Journal of the Physical Sciences. Vol. 6 (8), pp. 1974-1981. ISSN 1992-1950@2011. Academic Journals.

14. Kirov, B. (2003) Deformation properties of soft soil: oedometer testing. Proc. 2nd International Conference on Advances in Soft Soil Engineering and Technology (eds. B. Huat et al.) Putrajaya, Malaysia, pp. 49-51.

15. Landva, A. O. And La Rochelle, P. (1983) Compressibility and shear characterist ics of Radforth Peats. In P. M. Jarett (ed.), Testing of peats and organic soils, ASTM STP 820, pp. 157-191.

16. Lea, N. and Brawner, C. O. (1963) Highway design and construction over peat deposits in the lower British Colombia, Highway Research Record, 7, 1-32.

17. Lengkeek, H.K. the Use of Anisotropically Consolidated Triaxial, Direct Simple Shear and Constant Rate of Strain Tests in Determining the Strength Parameters of Organic Soft Soil. Proceedings of Soft Soils 2014, Bandung, Indonesia, H1.

Kompresibilitas Tanah Organik (Asriwiyanti Desiani) 
18. Mesri, G. and Ajlouni, M. (2007) Engineering properties of fibrous peats. Journal of Geotechnical and Geoenvironmental Engineering, 133(7), 850-66.

19. Mesri, G. and Godlewski, P. M. (1977) Time- and stress-compressibility interrelationship. Journal of Geotechnical Engineering, 103(GT 5), 417-30.

20. Mesri, G., Statark, T. D., Ajlouni, M. A. and Chen, C. S. (1997) Secondary compression of peat with or without surcharging. Journal of Geotechnical and Geoenvironmental Engineering, 123(5), 411-21.

21. Mesri, G., Statark, T. D., Ajlouni, M. A. and Chen, C. S. (1997) Secondary compression of peat with or without surcharging. Journal of Geotechnical and Geoenvironmental Engineering, 123(5), 411-21.

22. Mitchell, J. K. (1993) Fundamentals of Soil Behavior. John Wiley \& Sons, New York. Munro, R. (2004) Dealing with Bearing Capacity Problems on Low Volume Roads Constructed on Peat. The Highland Council, Transport, Environmental \& Community Service, Scotland, pp. 1-136.

23. Munro, R., (2004). Dealing With Bearing Capacity Problems on Low Volume Roads Constructed on Peat. Northen Periphery.ROADEX II.p. 5- 29, 34 - 63.

24. Wong, K. M. (2003) Earth-filling experiences on peat soils at Sri Aman, Sibu and Bintulu. Proc.2nd International Conference on Advances in Soft Soil Engineering and Technology (eds. B. Huat et al.), Putrajaya, Malaysia, pp. 669-79.

25. Yamaguchi, H., Ohira, Y., Kogure, K. and Mori, S. (1985) Undrained shear characteristics of normally consolidated peat under triaxial compression and extension conditions. Soils and Foundations, 25(3), 1-18.

26. Yogeswaran, M. (1995) Geological considerations in the development of Kuching area dialogue session. Geological and Geotechnical Considerations in Civil Works, Geological Survey of Malaysia, Kuala Lumpur.

27. Yulindasari, S. (2006) Compressibility characteristics of fibrous peat soil. Masters Dissertation, Universiti Teknologi Malaysia.

28. Zainorabidin, A. and Wijeyesekera, D. C. (2007). Geotechnical Challenges with Malaysian Peat. Proceedings of AC T, pp. 252-261. 